\title{
Kábítószer-élvezet és -függőség Magyarországon a 19. század végétől a második világháború kirobbanásáig
}

\section{ERDŐS Ákos ${ }^{1}$}

\begin{abstract}
Magyarországon, a büntetôjogi értelemben vett tiltott pszichoaktív anyagok, azaz a kábítószerek fogyasztását mint társadalmi jelenséget sokan az 1990-es évek rendszerváltozásának időszakához kötik, amikor a szabad mozgás, az országhatárok megnyitása lehetővé tette, hogy az országban különféle pszichoaktív anyagok jussanak be. A legtöbbek számára talán idegenként hat a 19-20. század fordulójának környékén élö, magyar droghasználó állampolgárok képe. Jelen tanulmány célja, hogy betekintést nyújtson a hazai kábítószer-használat azon - talán kevésbé közismert - időszakára, amely a 19. század második felétöl a második világháború kirobbanásáig tartott.
\end{abstract}

Kulcsszavak: kábítószer, drogfogyasztás, 19. század, 20. század, morfium, kokain, heroin, fogyasztó, kényszeres használó

Az emberi faj, mint minden más élőlény, fejlődése, történelme során - legmélyebb lényege szerint - mindig arra törekedett, hogy a létfeltételeit biztosítsa. ${ }^{2} \mathrm{Az}$ ösember és az ősi közösségek tagjai nolens volens szoros kapcsolatban kellett hogy együtt éljenek az őket körül vevő természeti környezettel és annak élővilágával. Az együttélés folyamatában, őseink gyújtögető-vadászó tevékenységük során időről időre olyan növényekkel, állatokkal találkoztak, amelyek elfogyasztását követően viselkedésük, tudatállapotuk megváltozott, szervezetük a megszokottól eltérően kezdett múködni.

A megváltozott pszichés állapot lehetőséget biztosított a nem evilági hatalmakkal történő kapcsolatteremtésre, az örömszerzésre, a betegségek leküzdésére és a harci erő fokozására egyaránt. Így tehát a kezdetekben véletlenszerủ droghasználat az idő során összegyüjtött tapasztalatok nyomán, egyre tudatosabbá vált.

Ma már pontosan tudjuk, hogy a tudatos droghasználat jelensége az emberiség történetének egy olyan részét képezi, amely az időszámításunk előtti évezredekbe nyúlik vissza. ${ }^{3}$ A legősibb kábítószerek egyike feltehetően az Indus völgyében használt

ERDŐS Ákos pénzügyőr őrnagy, egyetemi tanársegéd, NKE Rendészettudományi Kar, Vám- és Pénzügyőri Tanszéke, PhD-hallgató, NKE Rendészettudományi Doktori Iskola, addiktológiai konzultáns

Ákos ERDŐS customs major, assistant lecturer, NUPS Faculty of Law Enforcement Department of Customs and Finance Gurads, PhD. student, NUPS, subtance abuse consultant

orcid.org/0000-0001-9805-3511, erdos.akos@nav.gov.hu

2 Erdős (2012) 40.

3 Fürst-Wenger (2010) 14. 
indoarier volt, amelyet a muscimol hatóanyagot tartalmazó légyölő galóca préselt nedvéből állítottak elő. ${ }^{4}$

$\mathrm{Az}$ ember természetéből fakadó, antropológiai szempontból állandó igényének - a boldogság iránti vágy, az örömszerzés - kielégítése, minden kultúrában megteremtette ${ }^{5}$ és mind a mai napig fenntartja a különböző pszichoaktív anyagok fogyasztásának sajátos szokásait. Hartwich kutatására utalva Jakabházy Zsigmond megjegyzi, miszerint az élvezeti szer hatásainak a természete összhangban áll az azokat fogyasztó népek szokásaival, jellemével. Míg a mozgékony és harcias népek inkább az izgató, stimuláns anyagokat fogyasztják, addig „az ábrándozó, nyugodtan szemlélődő népek azon élvezeti szereknek adnak előnyt, melyek álmot vagy félálmot idézve elő, kellemes és szerelmes álomképeket támasztanak". ${ }^{6}$

A fenti megállapítások alól saját nemzetünk sem lehet, és nem is kivétel. A hazai kultúrában - más nemzetekhez hasonlóan - szintén megjelent a drogfogyasztás jelensége. Szinte bizonyos, hogy a magyar történelem első, tudatos pszichoaktív szerfogyasztói az ősi sámánok, táltosok voltak. A sámán volt a közösség azon képzett tagja, aki tudta, hogyan léphet be és miként tájékozódhat az eksztatikus sámáni tudatállapot világában, amelyet a pszichoaktív hatóanyagot tartalmazó növények, főzetek elfogyasztásával ért el. ${ }^{7} \mathrm{Az}$ ősi magyar sámánkultúra és a módosult tudatállapotban végzett szertartások emlékeit anyanyelvünk őrzi, a „regölés” kifejezésben. Karancz szerint: „a »haj regö rejtem« visszatérő kántálása nem más, mint a révületbe eső táltos elrejtőzött lelkére történő utalás". ${ }^{8}$

A pszichoaktív anyagok egy része - mint az alkohol, a dohány (nikotin) vagy a kávé (koffein) - mélyen beivódtak az emberek mindennapjaiba. A közösség lassanként kialakította azokat a normákat, kereteket, amelyek szem előtt tartásával ezen anyagok fogyasztását tolerálhatónak tekintette. Számos drog ugyanakkor kívül rekedt e kategórián, és azok előállítását, fogyasztását szigorúan szabályozni és tiltani kezdte az államok többsége, így hazánk is.

Magyarországon, a büntetőjogi értelemben vett tiltott pszichoaktív anyagok, azaz a kábítószerek, továbbá pszichotróp anyagok fogyasztását mint társadalmi jelenséget jellemzően az 1980-as 1990-es évek ópiátszármazékok, LSD, illetve kokain használatának terjedéséhez kötik. ${ }^{9}$ Más megközelítések már az államszocializmus időszakában drog indukálta társadalmi szintű problémákról beszélnek, amelynek első megjelenési formáját 1969-re datálják, amikor is először jelölik meg a tiltott drogfogyasztást egy haláleset közvetlen okaként, illetve ekkor készülnek az első beszámolók és jelentések az olyan csoportokról, akik kábítószer-élvezők voltak. ${ }^{10}$

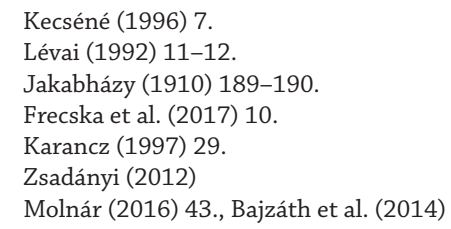


A legtöbbek számára talán idegenként hat az 1800-as évek második felében és az 1900-as évek elején élő, magyar droghasználó állampolgárok képe. A valóság ugyanakkor az, hogy hazánkban már a 19. század második, illetve a 20. század első felében is megfigyelhetők a kábítószer-használat társadalmi lenyomatai. Ahogy Donkó Erzsébet is megfogalmazta: „[A] ma kábítószer-probléma kutatója igencsak meglepődne, ha időben visszarepülhetne a századfordulótól 1945-ig terjedő időszak Magyarországába. Megdöbbenve tapasztalná, hogy a kábítószerek már abban az időben is a visszaélés eszközei voltak, a társadalom széles rétegei fogyasztották, termelték, árusították."11

Jelen tanulmány célja, hogy a korabeli források által betekintést nyújtson a hazai társadalom kábítószer-használói kultúrájának azon - talán kevésbé közismert - időszakára, amely a 19. század második felétől a második világháború kirobbanásáig tartott.

\section{Kábítószerek, a kóros örömszerzés eszközei}

\section{Ópium}

A magyar kábítószer-használói szubkultúra kezdeti állapotát bemutatva, érdemesnek tartom a legmeghatározóbb kémiai anyagcsoport vizsgálatával kezdeni, az ópiátokkal (az ópium és annak származékai).

Az ópium, a máknövény tejnedvének előállítása - a történelem előtti időkből - feltehetően Kis-Ázsiából ered. ${ }^{12}$ A különleges szer fájdalmat csillapító narkotikumként már az antik sebészeti gyakorlatban is megjelent. ${ }^{13}$ Nem csoda tehát, hogy a 20. századi nemzetközi kábítószer-szabályozás legfőbb okául, éppen az ópiummal és származékaival történő visszaélések - kelet-ázsiai - túlburjánzása szolgált.

$\mathrm{Az}$ ópium élvezeti cikként történő fogyasztása elsősorban a keleti, muszlim népek kultúrájában honosodott meg, ahol tiltott szer volt az alkohol. ${ }^{14}$ A 19. században ugyanakkor a gyarmattartó országokban (például Anglia, Egyesült Államok, Franciaország), a gyarmatokról hazatérő hajósok és katonák révén egyre inkább kezdett elharapózni az ópiumfogyasztás. ${ }^{15}$ A századfordulóra például számos francia kikötővárosban már annyi ópiumbarlang folytatta müködését, hogy a kormány kénytelen volt szigorú intézkedések bevezetésével útját állni a szenvedély terjedésének. ${ }^{16}$

A hazai orvosi gyakorlat - más európai nemzetekhez hasonlóan - szintén megtartotta az antik módszer alkalmazását. A méltán híres magyar orvos, Semmelweis Ignác 1843-as orvosavató vitájának tételei között meg is jegyzi: „opium és higany nélkül nem szeretnék orvos lenni". ${ }^{17}$

\footnotetext{
Donkó (1992) 9.

Bayer (2005) 25.

Birtalan (2015) 26.

4 Vizi (2006) 143.

15 Kátai (1859) 323.

6 Barla-Szabó (1913) 493.

17 Vida (1965) 653.
} 
A hazai népi gyógyászatban, házi praktikák körében is megtaláljuk a mákony használatát. A 19-20. század Magyarországán például sok esetben előfordult, hogy azokban a családokban, ahol nem volt olyan személy, akik az otthon maradó gyerekekre vigyázni tudott volna, magukra hagyták a gyerekeket. Annak érdekében, hogy a magára hagyott gyermek kárt ne tegyen magában, ópiumkészítményekkel, mákfőzetekkel nyugtatták. ${ }^{18} \mathrm{~A}$ sajátos gyermekóvó módszer alkalmazása többször is halálos következményekkel járt, ezért a 20. század első felében a szomszédos Ausztriában búncselekménnyé is minősítették azt. ${ }^{19}$ A korabeli közéleti források tanulsága szerint ugyanakkor hazánkban sokáig bevett szokás volt a borba vagy pálinkába mártott kenyér majszoltatása, illetve az ópiáttartalmú mákfőzet itatása. ${ }^{20}$ Még a szocializmus idején is előfordult, hogy mákfőzet okozta a csecsemő halálát. ${ }^{21}$

Ezek ellenére azt mondhatjuk, hogy a 19. században és a 20. század első felében az ópium mint kémiai komfortfokozó soha nem vált meghatározó anyaggá a magyar kábítószer-élvező szubkultúrában. Az Ujság 1926-os száma szerint: „az ópium budapesti terjedése a forradalom idejében kezdődött. Züllött spahitisztek mutatták meg először Budapestnek ezt a szinte ismeretlen szenvedélyt." ${ }^{22}$ Más források szerint viszont, hazánkban a századforduló után mindössze szórványosan akadtak hívei az ópiumszívásnak. Ők többnyire az országba betelepülő kínai házalók közül kerültek ki, akik hazájukból „hozták magukkal” a szenvedélyt, és később is elsősorban azzal hívták fel magukra a hatóság figyelmét, hogy heroin, morfium és kokain csempészésével és árusításával próbáltak plusz bevételre szert tenni. ${ }^{23}$

\section{Morfium}

Nálunk ebben az időszakban az ópium szerepét a morfium vette át. A morfin az ópium fő alkaloidja, amelyet Friedrich Wilhelm Adam német vegyész izolált először 1805-ben. A morfint nagyon hamar alkalmazni kezdték a gyógyászatban is, amely lassanként kiszorította a terápiásan nehezen adagolható ópiumkészítményeket. ${ }^{24}$

A mindennapi orvosi gyakorlat tapasztalataira alapozva lassanként felismerték a pszichoaktív anyagok használatával járó hozzászokás és függőség problémáját. ${ }^{25}$ Az 1880-as évektől egyre több értekezés látott napvilágot a morfinizmus terjedő jelenségéről a hazai tudományos folyóiratokban. Ezekben „divatos méreg”-ként beszélnek a morfiumról. ${ }^{26}$ Török Aurél 1884-es publikációjában kiemeli: „az emberiségnek legnagyobb csapását a bódító szerek: az ópium, morfium, hacsics képezik”. ${ }^{27}$

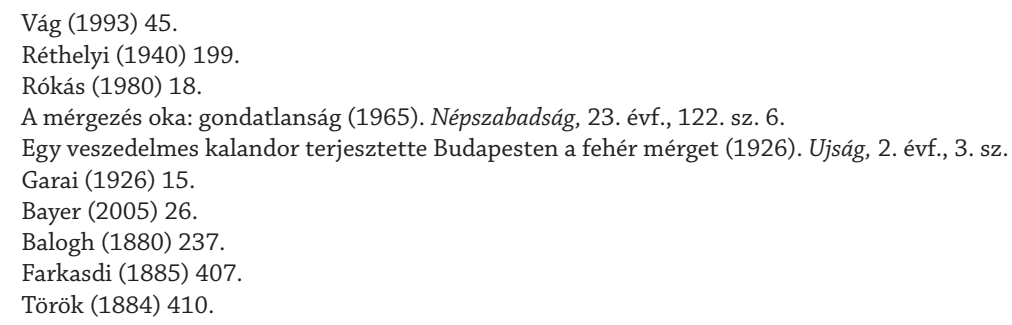


A századfordulót követően az egyre terjedő magyarországi morfiumhasználat következményeként végül a morfiumfüggőségről már „meglehetősen elterjedt betegségként" beszéltek szakmai körökben. ${ }^{28}$

Kezdetekben a morfinizmus terjedését világszerte számos olyan téves képzet táplálta, minthogy a morfin csupán lokálisan hat, és nem bír szisztémás effektusokkal a szervezetben: „A morfin hatása azon hely és tájra szorítkozik, melyen az égetőszer alkalmaztatott" - fogalmaznak az Orvosi Hetilap 1858-as számában. ${ }^{29}$ Az amerikai polgárháború idején (1861-1865) a brit vállalatok pedig egyenesen az ópiumfüggőség kezelésére alkalmas, illetve „függőséget nem okozó” fájdalomcsillapítóként értékesítették a morfiumot. ${ }^{30}$

A 19. század időszakában a morfinizmus elsősorban a jómódú férfiak körében - gyakran orvosoknál - volt jellemző. ${ }^{31}$ Száz használóból ötvenegy az egészségügyi ellátásban dolgozott mint orvos, orvosnövendék, betegápoló vagy apáca. ${ }^{32}$ És habár a probléma jellemzően a férfiakat érintette, a szerhasználók között jelentős számú nő is akadt. Megközelítőleg száz morfinista férfira huszonöt nő jutott. A kényszeres droghasználók először jellemzően gyógyászati kezelés során vagy egy már morfiumfüggő személy által kerültek kapcsolatba a kábítószerrel. ${ }^{33}$ Moravcsik szerint - ha másként nem sikerült - a droghasználók jelentős összegű vesztegetésekkel, orvosi receptek meghamisításával szerezték meg a vágyott anyagot. ${ }^{34}$ Súlyosabban fogalmaz Barla-Szabó József, aki szerint a kényszeres morfinista „csal, lop, receptet hamisít, vagy, amint már volt rá eset, öl, gyilkol a morphin megszerzéséért” ${ }^{35}$ A szert általában oldatként a bőr alá fecskendezve alkalmazták, esetenként pedig por vagy pirula formájában fogyasztották. ${ }^{36}$ A morfinizmus terjedésének kezdete tehát a 19. század második felére datálható, és nagyjából a Pravaz-fecskendők használatával esik egybe. ${ }^{37}$ Az 1853-ban, Charles Pravaz francia orvos által elsőként kifejlesztett fémfecskendőkkel ${ }^{38}$ ugyanis lehetővé vált a morfin subcutan módon történő hatékony alkalmazása.

A 20. század első évtizedei - különösen a háborús időszakot követően - jelentősen felgyorsult az ópiátok és más kábítószerek terjedése. Ebben szerepet játszott, egyrészt a tudomány fejlődése, amelynek nyomán egyre több fajta és egyre nagyobb mennyiségú pszichoaktív anyag került forgalomba, másrészt pedig a világháború és annak elvesztése, ami a sérülések, betegségek tömege és a nyomott társadalmi hangulat megfelelő táptalajt biztosított a kóros örömszerzés elterjedésének.

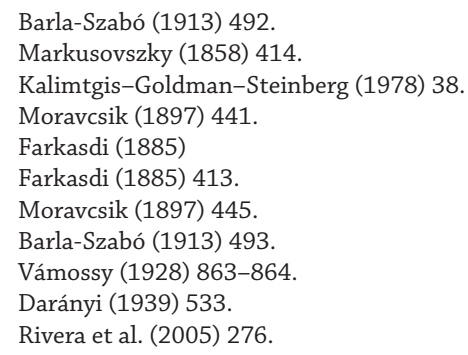


Az első világháború idején az ópium és morfium készítményeknek kiemelt szerep jutott. ${ }^{39}$ Kiválóan alátámasztja e megállapítást az anyagigényekről szóló korabeli forrás is, amely szerint: „[S]ok kell a következőkből: Háromszögű kendők (eddig 20 volt), légcső kanül (2 drb volt), citromsav, sok pugó, még több morphiuminj. (a sebesültek épp úgy sőt jobban morphiumozandók, mint az operált, kórházban fekvőknél szokásos)." ${ }^{40} \mathrm{~A}$ háborús körülmények mindamellett, hogy növelték az ópiátok iránti igényt, sok esetben el is lehetetlenítették azok beszerzését. A napi gyógyászatban alkalmazott narkotikum szükséglete a sérültek, betegek számával arányosan növekedett, mindazonáltal a nyers ópium Kis-Ázsiából történő beszerzését a Balkánon zajló háború akadályozta. ${ }^{41} \mathrm{Az}$ ópiummal ellentétben ugyanakkor ebben az időszakban sem a morfin, sem pedig a heroin kapcsán nem volt hiány. Ennek egyik oka, hogy 1913-ban és 1914-ben tetemes mennyiségű ópium felhasználásával, jelentős morfinkészletet (Dower-por) halmoztak fel ${ }^{42}$ itthon és más európai országokban egyaránt.

A fentieket figyelembe véve, nem is meglepő, hogy a nagy háború befejezését követően a kábítószer-élvezők száma jelentősen megnőtt hazánkban is. ${ }^{43} \mathrm{~A}$ háború évei felemésztették az emberek fizikai és pszichés tartalékait, így azok a könnyen megszerezhető kémiai örömök felé fordultak. Szabó Sándor országgyúlési képviselő 1930. június 17-i felszólalásában a következőképp fogalmazott erről: „[É]ppen a háború utáni rettenetes viszonyok között, amikor az idegrendszerben valóságos zavar állott elő a nagy szenvedések és nélkülözések után, az emberek különböző élvezetekben kerestek levezetést azokra a meghibbant állapotokra, amelyek az idegrendszert jellemezték és ebben a korszakban következett el aztán fokozottabban a visszaéléseknek egész láncolata." ${ }^{4}$

A háború után a hadsereg bomlása és a hadianyag széthordása alkalmával, a felhalmozott gyógyszerek, alkaloidák nagy mennyiségben kerültek a lakosság kezébe. Ezáltal a háború közvetett módon hozzájárult ahhoz, hogy - a pszichoszociális környezet mellett - biztosítottá váljon a szerhasználat „materiális” oldala is.

A morfium fogyasztása a társadalmi megoszlás tekintetében meglehetősen változatosnak mondható a 20. század első évtizedeiben. Tulajdonképpen minden társadalmi rétegben és mind a két nemnél előfordult valamilyen kábítószer fogyasztása. Az ópium alkaloidái, elsősorban a morfin, hazánkban főként a mưveltebb osztály köréből kikerülő egyéneknél fordult eló: számos orvos, gyógyszerész stb. - mint akik a szerhez aránylag könnyebben hozzájuthattak - lett a szenvedély rabja. ${ }^{45}$ Ezt támasztja alá Müller 1933-ban végzett kísérlete is, amely során Budapest öt legnagyobb gyógyszertárában vizsgálta meg az orvosi rendelvényeket. Eredményeit a következőképp foglalta össze:

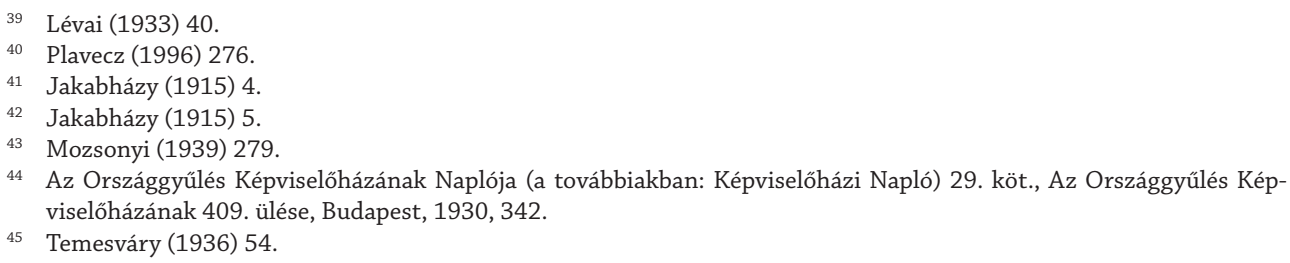


„[Á]tlagosan minden ötvenedik expedíció morfiumra esik. Már most ha számításba vesszük azt, hogy a gyógyszertárakon kívül is mily nagy mennyiség jut a morfinisták kezébe, úgy nem kell túlzottnak tekinteni Leschke berlini professzor ezévi becslését, mely szerint minden századik orvos morfinista" ${ }^{46}$

Ebbe a körbe tartozott a magyar író és orvos, Csáth Géza is, aki 1910-től kezdett el morfiumot használni, ${ }^{47}$ és életének is morfin, pantopon, illetve kokain túladagolásával vetett véget. ${ }^{48}$

Az értelmiség mellett a munkásosztály körében is megtízszereződött a morfinisták száma, és a 25 éven aluli fogyasztók aránya 40\%-ról 60\%-ra emelkedett. ${ }^{49}$ A morfinisták többsége 29 és 35 év közötti nőtlen férfi vagy hajadon nő volt. ${ }^{50}$ A világháború utáni morfinizmus oka az esetek 20-34,5\%-ában a harctéri szolgálat megterhelése, illetve sebesülés, 15,5\%-ában pedig a kíváncsiság, csábítás volt. ${ }^{51}$

Ahogy arra a korábbiakban utaltam, jelentős szerepe volt a szerhasználat terjedésében a tudomány - különösen a farmakológia - fejlődésének is. A 19. században közepén a kémiai tudományok fejlődése révén a századfordulóra közel tízezer vegyületet állítottak elő. ${ }^{52}$

1925-ben Kabay János, magyar gyógyszerész szabadalmaztatta a zöld máknövényből történő morfium izolálásának ipari technológiáját. Munkájának eredménye számszerű bizonyosságot nyert, ugyanis a hazai morfingyártás csakhamar világszínvonalúvá vált. Míg 1930-ban mindössze 5 kg morfint termelt, 1933-ban 192, 1936-ban már 724,5 kg morfin volt a Kabay-eljárás elve alapján múködő üzem termelése. Kempler Kurt szerint, nemzetközi szinten hazánkat többen azzal vádolták, hogy a magyar morfintermelés mögött kábítószer-élvezet, illetőleg annak a népesség körében történt nagy fokú elterjedése áll. ${ }^{53}$ A Népszövetség Kábítószerellenőrző Bizottsága ugyanakkor a Kabay-eljárás értékelése során épp azt emelte ki, hogy e módszerrel elkerülhetővé válik, hogy illegálisan állítsanak elő morfint. ${ }^{54} \mathrm{~A}$ tudományos fejlődés nyomában járó ópiát térnyerése következményeként, 1937-re a 4512 törzskönyvezett gyógyszerkészítmény közül 250-nek ópium, morfin vagy heroin volt a hatóanyaga. ${ }^{55}$

\section{Heroin}

Nem szabad megfeledkezni az egyik legjelentősebb félszintetikus morfinszármazékról sem, amely szintén a 19-20. század fordulóján jelent meg a szerhasználói szubkultúrában. A morfin acetilálásával előállított heroinról (diacetil-morfin) 1874-ben Robert

\footnotetext{
Müller (1933) 399.

Molnár (2014) 85.

48 Szajbély (1989)

49 Szieberok (1927) 1031.

50 Sziberok (1927) 981.

Szieberok (1927) 1031.

52 Tompa-Balázs (2018) 88.

3 Kempler (1964) 126.

Hosztafi (1997) 30.

5 Bayer (2011) 714.
} 
Alder Wright számolt be először. ${ }^{56} \mathrm{~A}$ kezdeti érdeklődést követően 1898 -ig nem jelent meg a szakirodalomban közlemény a heroinról.

Dreser, aki a köhögés csillapítására használt kodeinnél hatásosabb anyagot próbált keresni, 1898 őszén több tudományos közleményben ismertette eredményeit, amely meggyőzte a Bayer gyógyszergyárat, így még akkor megkezdték a diacetil-morfin sósavas sóját heroin néven gyártani és értékesíteni. ${ }^{57}$

Hazánkban Kétly László 1899-ben részletes tanulmányt publikált az új anyagról, amelyben - többek között - Dreser, Strube és Turnauer kutatási eredményeire, valamint saját megfigyeléseire hivatkozva kiemelte, hogy a heroin föképp köhögéscsillapításra használható, „fájdalomcsillapító hatása azonban teljesen hiányzik”. ${ }^{58} \mathrm{~A}$ heroin tehát kezdetben ígéretes pótszernek mutatkozott, amellyel a morfinizmusban szenvedőket lehet kezelni. A századfordulóra azonban a kezdeti lelkesedés alábbhagyott. Egyre többen ismerték fel ugyanis a heroin jelentős addikciós potenciálját. Tauszk Ferenc már 1898-ban leírta a herointoleranciával kapcsolatos tapasztalatait, miszerint betegeinél a heroin tartós adagolása mellett egyre nagyobb adagokat kellett alkalmazni. Azonban ekkor még továbbra is úgy vélte, hogy a kodeinnél semmivel sem károsabb. ${ }^{59}$

Issekutz Béla 1911-ben saját kutatási eredményeivel már cáfolja Dreser 1898-as megállapításait, és rámutat arra, hogy a heroin eredetileg javasolt gyógyító hatása nem is létezik. ${ }^{60} \mathrm{Az}$ 1910-es években már egyértelművé vált a szakemberek számára a heroin függőséget képező hatása is: „A heroin hatásában az összes morphin származékok közül leghasonlóbb a morphinhez, de mérgezőbb annál s a morfinizmushoz hasonló heroinizmus fejlődhet ki hosszabb használat után" - jegyzi meg Forgács Rezső 1919-ben. ${ }^{61}$

Az ópiumhoz hasonlóan a 20. század első évtizedeiben a kényszeres heroinhasználók száma jóval kevesebb volt a morfiumfüggőkhöz képest. ${ }^{62} \mathrm{~A}$ legnagyobb problémát az Egyesült Államokban, Kínában és Egyiptomban jelentette: New Yorkban például 1923-ra a kábítószerfüggók 98\%-a heroinista volt. ${ }^{63}$

A hazai heroinfogyasztók többsége az egészségügyből és más értelmiségi szakmákból - például politikusok, írók - közül kerültek ki. Kezdetben a heroin beszerzése nem okozott különösebb problémát, hiszen a patikában bárki hozzájuthatott, minthogy sokáig az orvosok ajánlották a morfium helyett. A heroinizmus terjedésének a szer betiltásával igyekeztek gátat vetni, és miután a legális forgalomból eltûnt, a továbbiakban a feketepiacon cserélt gazdát. A zugkereskedelemben „Etsch” és „Bia” néven ismerték a használók. ${ }^{64}$

\footnotetext{
Wright (1874) 1031-1043.

Hosztafi (2001) 234.

Kétly (1899) 1-3.

Tauszk (1898) 13-14.

Issekutz (1911) 1-18.

Forgács (1919) 106.

Sziberok (1927) 981.

Hosztafi (2001) 236.

Müller (1933) 401.
} 
Sokszor előfordult akkoriban az is, hogy a morfinizmus kínjaitól szenvedőket csaptak be nyerészkedő kuruzslók, és olyan különleges gyógyító szérumoknak titulált készítményeket adtak a függőnek, amelyek scopolamint, dionint vagy heroint tartalmaztak. E szerek használatával ugyanakkor csupán a morfiumtól szabadultak meg a betegek, de a függőségtől nem: mindössze szerváltás történt. ${ }^{65}$

1939-re az évi heroinfogyasztás hazánkban elérte az 1 kg-ot. ${ }^{66} \mathrm{~A}$ fogyasztást és a szerhasználót bemutató korabeli kép kissé másként festett, mint napjainkban. Ekkoriban ugyanis bőr vagy nyálkahártya alatti injekciózásokra többnyire az egyéb morfinszármazékok esetében került sor. A heroint azonban csaknem minden esetben szippantották a szerhasználók. ${ }^{67}$ Miután rájöttek, hogy sokkal jobban oldódik, mint a morfin sói, egyre inkább elterjedt az injekciós (intravénás) használata. A szakértők már ekkor problémaként vetették fel a heroinisták közös eszközhasználatát is, akik között a fecskendő kézről kézre járt, sterilizálás nélkül, és ez többek között a malária terjedésével fenyegetett. ${ }^{68}$

\section{Egyéb ópiátok}

A fentieken túl számos ópiumszármazék is részét képezte a 19., illetve a 20. század első évtizedei droghasználói szubkultúrájának. Ártatlanul hangzó nevek alatt külföldi gyárak, a morfiummal rokon és ugyanolyan hatású szereket hoztak forgalomba, amelyeket a kisebb fokú ellenőrzés folytán könnyen megszerezhettek a droghasználók. ${ }^{69}$

Hazánkban, elsősorban a pantopon (domopon, opium concentratum, exopon, holopon, laudanon stb.), az eucodal, a dicodid és az acedicon volt közkedvelt az ópiátélvezők körében. A világháború során jelentős mennyiségben került felhasználásra ezekből is - különösen codein és pantopon -, amely idővel készlethiányhoz is vezetett. ${ }^{70}$ Azonban míg a pantopon, az eucodal vagy akár a dicodid egyaránt képes volt arra, hogy könnyedén kialakítsa a kényszeres szerhasználói viselkedést, ${ }^{71}$ addig a codein esetében - az alacsony euforizáló hatás miatt - ez a veszély minimális volt. Bonhoeffer és Schwartz 1930-as publikációjára utalva a Budapesti Orvosi Újságban kifejtik, miszerint a codein utáni vágy kialakulásának megvan a reális esélye, azonban a 20. század első évtizedeiben ilyen esetek csupán szórványosan fordultak elő. ${ }^{72}$

Az 1920-as években - ritka jelenségként - a morfium és heroin kényszeres használata mellett pantoponismusról ${ }^{73}$ és eucodal-függőségről is beszámoltak a tudományos

\footnotetext{
Vámossy (1928) 465.

Mozsonyi (1939) 279.

67 Darányi (1939) 533.

68 Katona (1934) 302.

69 Barla-Szabó (1913) 494.

70 Jakabházy (1915) 7.

71 Csipke (1936) 95.

72 Frey (1931) 433-434.

73 Okolicsányi-Kuthy (1926) 658.
} 
folyóiratokban. ${ }^{74} \mathrm{~A}$ szakértők ekkorra azonban csaknem kivétel nélkül minden morfinszármazékkal kapcsolatban felhívták a figyelmet az addikció veszélyeire.

\section{Kokain}

Az ópiumszármazékok csoportja mellett, egy másik anyag is kitüntető helyet foglalt el a 19-20. század Magyarországának droghasználati közösségében. Ez pedig a tudományos körökben benzoil-ekgonin metilészternek nevezett kokain volt.

A kokain kivételes érzéstelenító és talán a leggyorsabban ható, legimpozánsabb kedélyjavító stimuláns. Miután a göttingeni vegyész, Albert Niemann 1859-ben izolálta a kokalevél hatóanyagát, ${ }^{75} \mathrm{az}$ anyag gyorsan közkedvelté vált a kontinensen.

Jakabházy szerint a kokainról szóló első átfogó tudományos munkát - jóval később - 1887-ben Don Julian Antonio publikálta, aki disszertációjában már a szer széles körü felhasználására buzdított. ${ }^{76}$ Valójában viszont a kokain sebészeti felhasználásáról, lokális aneszteziológiás alkalmazásáról Anrep már 1880-ban beszámolt, $A$ kokain élettani hatásairól címú munkájában. ${ }^{77}$ Schroff pedig ezt megelőzően - 1862-ben - írt a szer éredényeket szúkítő és pupillákat tágító hatásairól. Csakhamar kiderült ugyanakkor, hogy a kokainhasználat idővel kényszeressé válhat. Erlenmeyer 1886-os múvében már a „kokainizmus” jelenségére hívta fel a figyelmet. ${ }^{78}$ Egy évvel később Mattison pedig Kokain adagolás és kokainfüggöség címmel jelentette meg publikációját. ${ }^{79}$

Paradox módon, a kokain használatának terjedését a kezdetekben más pszichoaktív szerek, a morfium és az alkohol elleni küzdelem is táplálta. ${ }^{80} \mathrm{~A} 19$. században egy amerikai orvos ugyanis azt állította, hogy a kokain kiválóan alkalmazható a morfinelvonás tüneteinek enyhítésében. ${ }^{81}$ Tekintve, hogy a kokain hatástani szempontból alapvetően ellentétes a morfinnal, logikusnak mutatkozott az alkalmazása, a kor aggasztó jelenségeinek, a morfinizmus és az alkoholizmus kezelésére. Csakhamar világossá vált, hogy a morfinfüggőség effajta gyógyítása csupán a kokainizmus elterjedéséhez vezet. Ennek ellenére még a századfordulót követően is alkalmazták a kokaint a „morphiumtól való elszoktatásnál helyettesító szerként". ${ }^{82}$ A hazai kábítószer-használat terjedésének tehát részben a felelötlen, illetve hiányos ismeretekkel rendelkező orvosi gyakorlat volt az oka. ${ }^{83}$ Habár a droghasználat egészségügyi és életvezetési veszélyeire az újabb kori történelem során már a 17-18. században felhívták a figyelmet egyes kutatók és közéleti személyiségek ${ }^{84}$ a tudományos fejlődés vívmányaiként megjelenő új gyógyászati

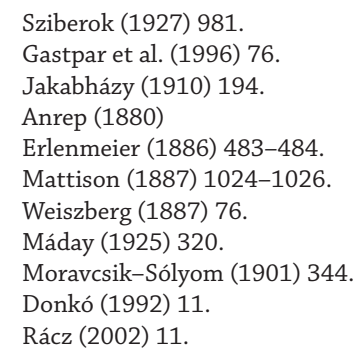


készítmények sok esetben - az ismeretek és tapasztalatok hiányában - könnyelmúen kerültek alkalmazásra az orvosi gyakorlatban. A medicina mindig csak később kezdte el felismerni az új szerek alkalmazhatóságának korlátait, így a kokainét is. Jól példázza ezt a Fogászati Klinika kurzistája, 1903-ban tett megállapítása, amelyben a következőképp fogalmaz: „[A]z akkori fogászatra jellemző, hogy érzéstelenítés még alig volt. Nagy szenzáció erejével hatott, hogy kokainnal lehet fogeltávolítást fájdalmatlanná tenni. Sajnos majdnem minden második beteg kokainmérgezéssel lefordult a székről."

Ebben az időszakban a kokainhasználók főként az orvosok és kórházi dolgozók köréből kerültek ki. Továbbá számos, anyagától megfosztott morfiumfüggő is fecskendezni kezdte a kokaint az elvont ópiát pótlására. ${ }^{86}$

A kokainizmus terjedése aztán az első világháború alatt és azt követően tovább fokozódott. A háború során - magától értetődő okokból - a francia, angol és orosz gyógyszerkészítmények, gyógyszer-különlegességek teljesen eltűntek. Ekkorra viszont már a központi hatalmak, a német és osztrák-magyar gyártású termékekből is ki tudták elégíteni az igényeket. Nem okozott tehát problémát a kokain, illetve az azt helyettesítő termékek - mint a novocain - előállítása és beszerzése sem. ${ }^{87}$ Részben erre vezeti vissza a kokain terjedésének okait Vámossy, aki szerint az újabb helyi érzéstelenítők - például a novocain - kiszorították a kokaint a piacról, és a nagyobb üzemek nem tudták törvényes úton értékesíteni termékeiket, így hát tiltott csatornákon adtak túl a felhalmozott kokainkészleteiken. ${ }^{88}$

A világháború utáni kokainabúzus terjedéséért ezzel szemben a háborúban testileg, lelkileg és gazdaságilag megtört nemzetek állapotát okolták, ${ }^{89}$ amelyet a gazdasági válság 1920-as évei tovább súlyosbítottak, hiszen sokan váltak munkanélkülivé, dologtalanná és élvhajhásszá a kor szakemberei szerint. A kábítószerhez hozzájutni jobbára erre specializálódott üzéreknél lehetett. A kokaincsempészek többnyire orosz katonák voltak ekkoriban, és ők osztották el a kábítószert a további értékesítőkhöz. ${ }^{90} \mathrm{Az}$ Ujság 1926. augusztus 26-i számában ezzel szemben a román megszállókat vádolták a kokain rohamos terjedésért. A cikk írója szerint a román katonák a háború utáni megszállás során belevetették magukat Budapest éjszakai életébe, és kuriózumként adták kóstolóul a kokaint a táncosnőknek és éjjeli lányoknak. ${ }^{91}$

A háború után a szerhasználók többsége már nem is az egészségügyi szolgálat dolgozói közül került ki. Legjelentősebb számban kávéházi dolgozók, pincérek, múvészek, artisták adták a kor fogyasztói és sokszor terjesztői csoportját. ${ }^{92}$ De elterjedt volt a kokainhasználat a revolverlapok szerkesztői, a zenészek és festők, ${ }^{93}$ valamint

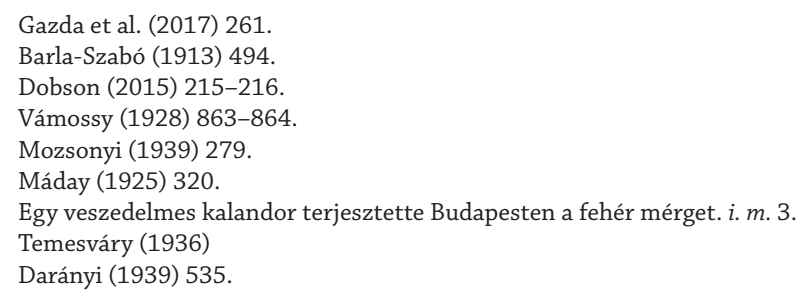


a homoszexuálisok, prostituáltak és munkanélküliek között is ${ }^{94}$ De nem volt példa nélküli a kokain használata a bünelkövetők körében sem. Esetükben ugyanakkor Temesváry szerint - elsősorban azért vált közkedvelté a stimuláns szer használata, mert abból meríthették „a büncselekmény elkövetéséhez szükséges lelkierejüket”. ${ }^{95}$

A kokainisták eleinte javarészt 25 éves átlagéletkorú nőtlen férfiak vagy hajadon nők voltak, ${ }^{96}$ azonban az 1920-as évek végére egyre több gimnazista és serdületlen korú fiatal is elkezdte használni a stimulánst. ${ }^{97}$

Az állami apparátus által toxikomániásnak vélt személyekről vezetett nyilvántartásban 1935 végén 109 fö (39 férfi, 70 nő) szerepelt..$^{98} \mathrm{~A}$ nyilvántartottak között jelentős mennyiségben voltak a kéjnők.

Ez utóbbi adattal kapcsolatban ugyanakkor fontosnak tartom megjegyezni, hogy a nemek közötti megoszlásban feltűnően nagy ellentmondás érezhető. Kiváltképp, ha azt is számba vesszük, hogy a nyilvántartottak majdnem mindegyike kokainista volt. A kábítószerek fogyasztóinak történelmi vizsgálata során, egészen napjainkig megállapítható, hogy azokkal többségében inkább a férfiak éltek. Kiváltképp a kokain esetében. Véleményem szerint a korabeli nyilvántartásban a nemek közötti fordított arányosság, a nyilvántartottak jelentős részének foglalkozásával (kéjnők) áll összefüggésben. Hiszen a prostituáltak már akkor is nagyobb eséllyel kerültek kapcsolatba a rendőrhatósággal, erkölcstelennek tartott életvitelük okán, így természetes, hogy az éjszakai élet szerfogyasztói közül elsősorban közülük kerültek ki a később regisztrált toxikomániások is. Feltehetőleg ez okozta a hatóság nyilvántartásában a nemek megoszlása közötti aránytalanságot.

1939-re már 170 toxikomániást tartottak nyilván. Azonban még ekkor is kiemelkedő többségben voltak a regisztráltak között prostituáltak (54 fö), valamint egészségügyi dolgozók, akik közül 15 orvos, 6 pedig gyógyszerész volt. ${ }^{99}$

A forgalomban lévő 25-50\% töménységủ kábítószer legtöbbször az utcán vagy klubokban cserélt gazdát, a „tolvajnyelv" különböző fantázianevei alatt, mint például kokó. ${ }^{100}$ Vámossy szerint sok esetben az első adagot ingyen kínálták a terjesztők az újonnan próbálkozó szerhasználók között. ${ }^{101}$ Budapesten az 1920-as évek végén rohamosan terjedő kokainhasználat hazai „ősforrásának” Sohár Elek helyi vegyészt tekintették, aki Lexi becenéven vált ismerté a kábítószer-használók körében, mint az első kokainterjesztő́k egyike. ${ }^{102}$ Mindazonáltal számos más orvosról, vegyészról és gyógyszerészrôl is beszámoltak a korabeli lapok, akik szintén a kábítószerek illegális kereskedelmével igyekeztek szert tenni további jövedelemre.

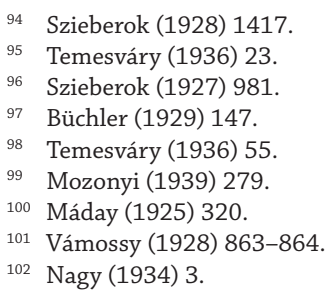


A korszakot jellemző kokainfogyasztó szubkultúra kapcsán elmondható, hogy elsősorban az éjszakai élet, a szabadelvűség és szabadgondolkodás képviselői nyúltak ehhez a szerhez. A kokain 19-20. századi terjedésével végül olyan közismert személyiségek is rendszeres használóvá váltak, mint Sir Arthur Conan Doyle, Alexandre Dumas, Ibsen, Verne vagy a pszichoanalízis atyja, Sigmund Freud, aki terápiás eszközként tekintett a csodálatos anyagra, s fiatal menyasszonyának is lelkesen ajánlotta a szert. ${ }^{103}$ Hazánkban, korának közismert irodalmi alakja, Kosztolányi Dezső is rendszeres kokainhasználó volt. „Fiatal korában súlyos szénanátha gyötörte, s hogy csökkentse az orrnyálkahártya ingerlékenységét, gyógyszerész ismerőseitől vagy rokonaitól szerzett kokainnal ecsetelgette. Az antiallergiás hatás lassan szenvedéllyé vált. Az anyai ágon patikus família és orvos barátai hosszú ideig gyanútlanul látták el az egyre híresebb írót, ezt a »csekélységet« indokoltnak és veszélytelennek vélték. Feleségének feltűnt, hogy bár szeszes italt nem fogyasztott, mindig olyan volt »mint aki egy kicsit mámoros«. Később talált rá a kis üvegre, amelyben a mérget rejtegette."104

A szerhasználat jelenségének elterjedésével eltérő tapasztalatok alakultak ki a kokainfogyasztás módját illetően is. Egyesek úgy látták, hogy a kokainisták legnagyobb része szívja a kokaint, mint az ópiumot, és csak később térnek rá a fecskendőre. ${ }^{105}$ Míg mások ennek az ellenkezőjét tapasztalták, miszerint hogy a heroinnal ellentétben a kokaint szinte kizárólag bőr alatti, úgynevezett subcutan injekciózással volt használatos, és ezt váltotta később a por halmazállapotú anyag felszippantása, amely fokozatosan kiszorította az injekció alkalmazását. ${ }^{106}$

A fentiek alapján elmondható, hogy a kokain meghatározó szerepet töltött be a 1920. század fordulóján élő kábítószer-használói szubkultúrában. 1938-ra, az évi fogyasztás hazánkban, egymillió lakosra kivetítve a kokain esetén elérte a 2,2 kg-t. Ekkor csak a büdszentmihályi gyógyszerüzem évente 20-22 kg kokaint állított elő. ${ }^{107}$

A különböző drogok indukálta egészségügyi károsodásokat jól példázzák a század elejéről származó statisztikai mutatók. Budapest öt ideggyógyintézetéből származó adatok szerint, a kezelt betegek 0,26\%-a volt kokain-, illetve morfiumfüggő 1912 és 1914 között. 1924-re ezen addiktív páciensek száma elérte a 2-5\%-ot, amely arány a második világháborút követően csak tovább növekedett. ${ }^{108} \mathrm{~A}$ kényszeres kémiai szerhasználók eredményes gyógykezelésére már az 1800-as évek végén külön erre a célra szolgáló intézetek kialakítását javasolták a szakértők. ${ }^{109}$ Így a századforduló első éveiben, például a fővárosban, már külön szanatóriumba hirdettek felvételt alkoholista és morfinista betegek számára. ${ }^{110}$

\footnotetext{
103 Huber-Kisszékelyi-Németh (1989) 16.

104 Szállási (1985) 3219.

105 Darányi (1939) 535.

106 Temesváry (1936)

107 Mozonyi (1939) 279.

108 Mátyus (2012) 10.

109 Moravcsik (1897) 448.

110 Lenhossék-Székely (1909) 457.
} 
Az egészségügyi kockázatokat értékelve pedig, az már a második világháborút megelőzően is nyilvánvaló volt a szakértők számára, hogy a kor két közkedvelt pszichoaktív szertípusa, az ópiumszármazékok és a kokain is egyaránt alkalmas a szerfogyasztók halálának előidézésére. Elméleti ismereteiket gyakorlati tapasztalások támasztották alá. Temesváry a következőképp fogalmaz: „Öngyilkossági és véletlen halálesetet az opium és a morphin meglehetősen gyakran idéz elő.” A kokainhasználat esetében hasonlóan borús képet fest a szerző a korabeli állapotokról. „Az elhalálozások gyakoriságát illetően megbízható statisztikai adatokkal nem rendelkezünk; nem kétséges azonban, hogy gyakrabban fordulnak elő, mint ahogyan azt általában feltételezik."111

\section{Befejezés}

A kokain és a különböző ópiátszármazékok elterjedését követően - a második világháború kirobbanásához közeledve - újabb pszichoaktív anyagok jelentek meg a kontinensen, amire az addigi tapasztalatok miatt korán felfigyelt a társadalom. Az 1930-as években például, az Európában megjelenő marihuána „irtózatos” az „eddigieknél sokkal veszedelmesebb" kábítószerként vonult be a köztudatba. ${ }^{112}$ De ebből az időszakból származik a hasis, valamint a meszkalin elterjedései is az öreg kontinensen. ${ }^{113}$

Napjaink élmény- és eredményorientált világából visszatekintve láthatjuk, hogy az emberi vágyak kielégítésének vagy a pszichoaktív anyagok fogyasztásának igénye nem a felgyorsult, globalizált 21. század sajátos terméke. A drogfogyasztás jelensége ugyanis nem nemzeti vagy korszakos sajátosság, hanem elsősorban emberi specifikum. Mint ahogy az anyaggal szembeni káros szenvedély kialakulásáért sem lehet önmagában a kémiai szert okolni, úgy a droghasználat jelenségét sem tekinthetjük kizárólag a modern világ következményének.

A 19. végének és 20. század elejének történelmi eseményei, társadalmi változásai épp úgy megteremtették a szerhasználat pszichoszociális környezetét, mint napjaink stresszel terhelt világa. Az egyént - ezekben az évtizedekben, csakúgy mint napjainkban - pszichésen és fizikálisan egyaránt megviselték környezetének hatásai, amelyre mintegy maladaptív megküzdési mechanizmusként jelentkezett a droghasználat.

A mai drogpolitika alapvetően kirekesztő és stigmatizáló, amely a fogyasztók üldözésére, elzárására helyezi a megoldás elemi pontjait. ${ }^{114}$ Ahhoz, hogy megértsük napjainkban a droghasználathoz kapcsolódó társadalmi jelenségeket, a fogyasztók vagy az állam álláspontját e kérdésben, elengedhetetlen, hogy visszatekintsünk a múltba. E tanulmány segítséget nyújt abban, hogy laikus és szakavatott egyaránt betekintést nyerhessen egy ma is aktuális, s a legtöbbek számára fontos és érdekes jelenség valódi gyökereihez.

\footnotetext{
111 Temesváry (1936) 13-19.

112 Irtózatos új kábítószer fenyegeti Európát (1937). 8 Órai Újság, 23. évf. 110. sz. 8.

113 Müller (1933) 402.

114 Erdős (2015) 23.
} 


\section{FELHASZNÁLT IRODALOM}

A mérgezés oka: gondatlanság (1965). Népszabadság, 23. évf., 122. sz.

Anrep, B. von (1880): Ueber die pshysiologische Wirkung des Cocain. Pflugers Arch., Vol. 21. No. 1. 38-77.

Balogh Kálmán szerk. (1880): Megszokás bizonyos mérgek iránt. Természettudományi Közlöny, 12. évf. 130. sz. 237-238.

Bajzáth Sándor - Tóth Eszter Zsófia - Rácz József (2014): Repülök a gyógyszerrel. Budapest, L’Harmattan.

Bayer István (2005): Drogok és emberek. Budapest, Focus Kiadó.

Bayer István (2011): Mérlegen a valóság: siker vagy kudarc? Az 1961. évi Egységes Kábítószer-egyezmény értékelése az 50. évforduló alkalmából. Gyógyszerészet, 55. évf. 12. sz. 714-724.

Barla-Szabó József (1913): A morphinismus. Uránia, 14. évf. 12. sz. 492-494.

Birtalan Győző (2015): A modern hadegészségügy szervezeti kialakulásának kezdete külföldön és hazánkban. In Kapronczay Károly szerk.: Háború és orvoslás. Az I. világháború katonaegészségügye, annak néhány elözménye és utóélete. Budapest, Magyar Orvostörténelmi Társaság.

Büchler Pál (1929): A morphinismus, cocainismus és kezelésük. Orvosi Hetilap melléklete, 73. évf. 37. sz. 147-148.

Csipke Zoltán (1936): Nemhivatalos gyógyszerek és vegyszerek vizsgálata és használata. Budapest, Pápai Ernő Műintézete.

Darányi Gyula (1939): Közegészségtan I. Budapest, Magyar Orvosi Könyvkiadó Társulat.

Dobson Szabolcs (2015): Az I. világháború és a gyógyszerek. In Kapronczay Károly szerk.: Háború és orvoslás. Az I. világháború katonaegészségügye, annak néhány elözménye és utóélete. Budapest, Magyar Orvostörténelmi Társaság.

Donkó Erzsébet (1992): A hazai drogproblémák a századfordulótól a második világháborúig. In Gerevich József - Veér András szerk.: A kábítószer kihívása. Budapest, Gondolat Könyvkiadó.

Egy veszedelmes kalandor terjesztette Budapesten a fehér mérget (1926). Ujság, 2. évf.

Erdős Ákos (2012): Felelősség a rendvédelemben, múltban és jelenben. Rendvédelmi Füzetek, 1. évf. 2. sz. $40-76$.

Erdős Ákos (2015): Droghelyzet: tiltás kontra legalizáció. Magyar Rendészet, 15. évf. 3. sz. 11-26.

Erlenmeyer, Albrecht (1886): Uber cocainsucht. Deutsche Medizinal-Zeitung, No. 7. Vol. 44. 483-484.

Farkasdi Sörös L. (1885a): Két divatos méreg. A morfium és az éther. I. rész. Természettudományi Közlöny, 17 (194): 407-413.

Frecska Ede - Kovács Attila - Jeges Balázs - Gajdos Ágoston (2017): Nonlokalitás és a sámáni tudatállapot. In Czövek Judit - Szulovszky János szerk.: Közvetítő. Tanulmányok Hoppál Mihály 75. születésnapjára. Budapest, Magyar Vallástudományi Társaság.

Frey Ernő szerk. (1931): Az idült codeinismus kérdéséhez. Budapesti Orvosi Újság, 29. évf. 16. sz. 433-434.

Forgács Rezső (1919): Utbaigazitások a kézi eladáshoz a modern gyógyszerhatástan szempontjából. Gyógyszerészi Hetilap, 58. évf. 9. sz. 104-106.

Fürst Zsuzsanna - Wenger Tibor szerk. (2010): A kábítószerabúzus orvosi, jogi és társadalmi vonatkozásai. Budapest, Medicina Kiadó.

Garai F. szerk. (1926): Az édes méreg. Tolnai Világlapja, 26. évf. 33. sz. 14-15.

Gastpar, Marcus M. - Kasper, Siegfried - Linden, Michael ed. (1996): Psychiatrie. Berlin - New York, Walter de Gruyter.

Gazda István - Kapronczay Károly - Szállási Árpád szerk. (2017): A múlt magyar orvostörténészei. Budapest, Magyar Tudománytörténeti és Egészségtudományi Intézet.

Hosztafi Sándor (1997): Kabay János, a magyar morfingyártás megalapítója. Gyógyszerészet, 41. évf. 1. sz. 25-37.

Hosztafi Sándor (2001): A heroin története. Acta Pharmaceutica Hungarica, 71. évf. 2. sz. 233-242. 
Huber Béla - Kisszékelyi Ödön - Németh Zsolt (1989): A bódulat csapdájában. Budapest, Tankönyvkiadó Vállalat.

Issekutz Béla (1911): Nehány anyag lélekzésre való hatásának összehasonlító vizsgálata. A Morphinum és származékai. Értesitő az Erdélyi-Múzeum-Egyesület Orvostudományi Szakosztályából, 33. évf. 1. sz. 2-45.

Jakabházy Zsigmond (1910): A különféle élvezeti szerekről. Értesítő az Erdélyi Múzeum-Egyesület Orvostudományi Szakosztályából, 35. évf. 32. sz. 188-201.

Jakabházy Zsigmond (1915): A háború és a gyógyszerek. Értesítő az Erdélyi Múzeum-Egyesület Orvostudományi Szakosztályából, 37. évf. 1. sz. 1-15.

Kalimtgis, Konstandinos - Goldman, David - Steinberg, Jeffrey ed. (1978): Dope Inc. Britain’s Opium War Against the U.S., New York, The New Benjamin Franklin House.

Karancz Gábor (1997): „Pedagógusok” az ún. Kassai kódexben. Iskolakultúra, 7. évf. 1. sz. 26-31.

Kátai Gábor (1859): Mákony - Opium. I. rész. Orvosi Hetilap, 3. évf. 20. sz. 323-326.

Katona József (1934): A malária mesterséges átvitele intravénás diacetyl-morphin-élvezők között. Orvostudományi Szemle, 9. évf. 9-10. sz. 302-303.

Kecséné Dravecz Márta (1996): Kábítószerismeret. Budapest, VIVA Média Holding.

Kempler Kurt (1964): A gyógyszerek története. Budapest, Gondolat Kiadó.

Kétly László (1899): Néhány újabb gyógyszerről szerzett klinikai tapasztalatok. Heroin. Orvosi Hetilap melléklete, 43. évf. 26. sz. 1-3.

Lenhossék Mihály - Székely Ágoston szerk. (1909): Vegyes hírek. Orvosi Hetilap, 53. évf. 25. sz. 457.

Lévai Jenő (1933): Éhség, árulás, Przemysl. Budapest, „Magyar Hétfő”.

Lévai Miklós (1992): A kábítószer-probléma és a büntetőjogi kontrollja Magyarországon. Esély, 4. évf. 1. sz. 56-63.

Máday István (1925): Cocainismus. Budapesti Orvosi Újság, 23. évf. 11. sz. 320-321.

Markusovszky Lajos szerk. (1858): Helybelileg érzéktelenítő (Anesthesique) szer edző szerekbe vegyítve. Orvosi Hetilap, 2. évf. 26. sz. 413-415.

Mattison, Jansen B. (1887): Cocaine Dosage and Cocaine Addiction. The Lancet, Vol. 129. No. 3325. 1024-1026.

Mátyus Mária (2012): A kábítószer fogyasztás vizsgálata a Magyar Honvédség állományánál különös tekintettel az ópiátokra. Doktori disszertáció, kézirat, Budapest, Nemzeti Közszolgálati Egyetem.

Molnár Dániel (2016): Kábitószer-politika Magyarországon 1990 és 2014 között. Doktori disszertáció, kézirat, Pécs.

Molnár Eszter Edina (2014): Csáth Géza tragédiája. Psziché és történelem. Aetas, 29. évf. 3. sz. 78-96.

Moravcsik Ernő Emil (1897): Gyakorlati elmekórtan. Budapest, Magyar Orvosi Könyvkiadó Társulat.

Moravcsik Ernő Emil - Sólyom Andor (1901): Az orvosi müködés köre az igazságügyi közszolgálatban. Budapest, Magyar Orvosi Könyvkiadó Társulat.

Mozsonyi Sándor (1939): A kábítószerügy gyógyszerészi vonatkozásai. A Magyar Gyógyszerésztudományi Társaság 1939. IV. 14-i ülésén elhangzott előadása. Sajtó alá rendezte: Halmai János. Gyógyszerészi Közlöny, 55. évf. 16. sz. 278-280.

Müller Imre (1933): Narkománia. Magyar Szemle, 19. évf. 73. sz. 393-404.

Nagy S. szerk. (1934): A „koko” pesti tündöklése és bukása. 8 Órai Ujság, 20. évf. 211. sz. 3-5.

Okolicsányi-Kuthy Dezső (1926): A köhögésről és a köhögéscsillapító szerekről. Budapesti Orvosi Újság, 24. évf. 22. sz. 658.

Plavecz Tibor (1996): Magyar honvéd- és katonaorvosok tapasztalatai az első világháborúban. Orvostörténeti Közlemények, 41-42. évf. 1-8. sz. 251-310.

Rácz József szerk. (2002): Drog és társadalom - az addikció mintázatai. Budapest, Új Mandátum Könyvkiadó.

Réthelyi J. szerk. (1940): Mérgek és ellenmérgek. Gyógyszerészi Hetilap, 79. évf. 20. sz. 198-199.

Rivera, A. M. - Strauss, K. W. - van Zundert, Adrian - Mortier, Eric (2005): The history of peripheral intravenous catheters: How little plastic tubes revolutionized medicine. Acta Anaesthesiologica Belgica, 56. évf. 3. sz. 271-282.

Rókás S. (1980): Élvezeti (?) cikkek. Népszabadság, 38. évf. 187. sz. 18. 
Szajbély Mihály (1989): Csáth Géza. Budapest, Gondolat Kiadó.

Szállási Árpád (1985): Kosztolányi, az orvosok és a betegsége. Orvosi Hetilap, 126. évf. 52. sz. 32183222.

Sziberok Ferenc (1927): A részegítő és narkotikus mérgekről. Budapesti Orvosi Újság, 25. évf. 34. sz. 979-981.

Tauszk Ferenc (1898): Heroin a morphin egy új pótszere. Orvosi Hetilap melléklete, 42. évf. 50. sz. 12-14.

Temesváry György (1936): A kábítószerekrôl - különös tekintettel az általuk elöidézett kóros megszokás és a toxicomania elleni küzdelemre. Budapest, Hornyánszky Viktor R-T. Magyar Királyi Udvari Könyvnyomda.

Tompa Anna - Balázs Péter (2018): A toxikológia rövid története - a tapasztalattól a tudományig. Orvosi Hetilap, 159. évf. 3. sz. 83-90.

Török Aurél (1884): A betegségek uralma a Föld népei közt. Természettudományi Közlöny, 16. évf. 182. sz. 393-410.

Vág Ottó (1993): A kisgyermeknevelés története. Miskolc, Magyar Óvodapedagógiai Egyesület.

Vámossy Zoltán (1928): Élvezeti szereink méreghatása. Természettudományi Közlöny, 60. évf. 863-864. sz. 457-467.

Vida Tamás (1965): Semmelweis „az anyák megmentője”. Vigilia, 30. évf. 11. sz. 653-659.

Vizi E. Szilveszter (2006): Kábítószerek - a kreativitás mítosza és a rombolás valósága. Mindentudás Egyeteme 6., Budapest, Kossuth Kiadó. 141-163.

Weiszberg Zsigmond (1887): A legújabb divatú mérgek. Természettudományi Közlöny, 19. évf. 210. sz. 76-79.

Wright, Robert Adler (1874): On the Action of Organic Acids and their Anhydrides ont he Natural Alkaloids. Journal of the Chemical Society, Vol. 27. 1031-1043.

Zsadányi Zsuzsa (2018): A drogfogyasztás alakulása Magyarországon. A drogfogyasztás faktorai. Mindennapi Pszichológia. Forrás: http://mipszi.hu/cikk/130309-drogfogyasztas-alakulasa-magyarorszagon (2018. 01. 18.)

\section{ABSTRACT}

\section{Drug Use and Addiction in Hungary from the Second Half of the $19^{\text {th }}$ Century until the Beginning of World War II}

ERDŐs Ákos

In these days, most people may think that drug use as a social phenomenon in Hungary appeared in the 1990s. It was identified that the spread of drugs was the result of opening borders and freedom of movement. Most of us may not be able to imagine the picture of Hungarian drug users in the $19^{\text {th }}-20^{\text {th }}$ centuries.

This paper tries to show the trends of drug use between the second half of the $19^{\text {th }}$ century and the beginning of World War II.

Keywords: drug, drug use, $19^{\text {th }}$ century, $20^{\text {th }}$ century, morphium, cocaine, heroin, drug user, drug addict 